\title{
EFFECT OF WATER ON BIMODALITY OF AIR TEMPERATURE DISTRIBUTION FUNCTIONS AND CHANGES IN T-YEAR AIR TEMPERATURE VALUES IN HURBANOVO
}

\author{
Pavla Pekárová, Ján Pekár, Pavol Miklánek
}

\begin{abstract}
Variability and long-term trends in air temperature are in the interest of hydrologists in recent decades as they can affect the global hydrological cycle and water balance in river basins. The estimation of the $T$-year minimum and maximum mean daily air temperature is associated with the problem of selection of the distribution functions of these series. The histograms of the daily air temperature series manifest the two-peak (bimodal) shape in many stations all over the world. It is not feasible to describe the distribution function of bimodal distribution through single mean value and single standard deviation. In the present study the $T$-year values of air temperature are estimated for three temperature indexes in station Hurbanovo: 1 . series of maximum mean daily air temperature of the year $T_{d, m a x}, 2$. series of mean annual air temperature of the year $T_{d}$; and 3. series of minimum mean daily air temperature of the year $T_{d, \min }$. Change in the theoretic distribution curve of the mean daily air temperature indexes is compared during two subperiods of the instrumental period 1872-2017. Generally, the changes in temperature design values are more marked in case of minimum temperatures, e.g. the value of 100 -year minimum mean daily air temperature increased by more than $5^{\circ} \mathrm{C}$. The 100 -year maximum mean daily air temperature increased by $1.88^{\circ} \mathrm{C}$ in Hurbanovo.
\end{abstract}

KEY WORDS: air temperature, Hurbanovo, bimodal distribution, T-year values

VPLYV VODY NA BIMODALITU DISTRIBUČNÝCH FUNKCIÍ TEPLOTY VZDUCHU A ZMENY $N$ - ROČNÝCH HODNÔT TEPLOTY VZDUCHU V HURBANOVE. Variabilita a dlhodobé trendy teploty vzduchu sú v posledných desat'ročiach v centre pozornosti hydrológov, pretože môžu ovplyvnit' globálny hydrologický cyklus a bilanciu vody v povodiach. Určenie $N$-ročných minimálnych a maximálnych priemerných denných hodnôt teploty vzduchu je spojené s problémom nájdenia distribučných funkcií týchto radov. V mnohých staniciach na svete majú histogramy denných radov teploty vzduchu dvojvrcholový (bimodálny) tvar. Opísat’ distribučnú čiaru bimodálnej distribúcie jednou strednou hodnotou a jednou smerodajnou odchýlkou nie je prípustné. V predloženom príspevku sú na príklade údajov zo stanice Hurbanovo určené $N$-ročné hodnoty teploty vzduchu pre tri teplotné indexy: 1. rad zostavený z maximálnych priemerných denných teplôt vzduchu v roku $T_{d, m a x} ; 2$. rad priemerných ročných teplôt vzduchu $T_{d}$; a 3 . rad minimálnych priemerných denných teplôt vzduchu v roku $T_{d, \min }$. Porovnané sú zmeny teoretických distribučných čiar pre rady vybraných indexov za rôzne časové podobdobia rokov 1872 - 2017. Vo všeobecnosti výraznejšie zmeny návrhových hodnôt teplôt nastali v prípade minimálnych teplôt, hodnoty 100 -ročnej minimálnej priemernej dennej teploty sa zvýšili o viac ako $5^{\circ} \mathrm{C}$. Storočná maximálna priemerná denná teplota vzduchu v Hurbanove sa zvýšila o $1,88^{\circ} \mathrm{C}$.

KLUUČOVÉ SLOVÁ: teplota vzduchu, Hurbanovo, bimodálne rozdelenie, $N$-ročné hodnoty

\section{Úvod}

The knowledge of the extreme air temperature development is very important for hydrology and water balance in each country (Szolgay et al., 2002; 2007). The natural processes usually display the unimodal (single-peak) symmetric shape of the histogram (distribution function).
In case of the air temperature it is valid e.g. for the series of mean annual air temperature, or seasonal air temperature series. In majority of stations over the world the distribution of mean daily air temperatures has bimodal (two peak) shape. Majority of stations in Slovakia belongs to this type as well. At station Hurbanovo (Fig. 1a), the histogram of mean daily air 
temperature, as well as histograms of minimum/ maximum daily air temperature, have bimodal shape.

Fig. 1a demonstrates that one peak occurs in class of $+2^{\circ} \mathrm{C}$. The bimodality of the mean daily air temperature histograms is usually explained through different conditions during summer and winter seasons. We are of the opinion that the reason for occurrence of increased number of mean daily temperatures in span of 0 to $+2^{\circ} \mathrm{C}$ is the amount of heat used in liquid/solid state transition in wider surroundings of the climatic station (in atmosphere, in soil, in rivers and lakes) and vice versa (Pekárová et al., manuscript). Due to it the temperature between $0^{\circ}$ and $+2^{\circ} \mathrm{C}$ occurs more often and they have higher frequency. In high mountain stations (e.g. Lomnický štít), where the mean annual air temperature is near to $0^{\circ} \mathrm{C}$ the both peaks merge into single peak and the histogram obtains single peak/unimodal shape (Fig. 1b).

Bimodality of the distribution functions of air temperature series complicates the possibility of selection of the theoretical distribution function of daily air temperature series and the estimation of the distribution of daily (minimum, mean, maximum) air temperatures in future in conditions of the expected atmosphere warming based on historical observations. At the same time the knowledge of the future development of temperature is in the center of interests of each country due to the increasing impact of increasing air temperature on society and economy (Melo et al., 2007; Melo and Lapin, 2000).

In this paper we focused on assessment of changes of the theoretical distribution functions of selected series of minimum and maximum (mean daily) air temperatures at station Hurbanovo during four 60-years periods: 1872-1931, 1901-1960, 1931-1990, 1958-2017.

\section{Data used and methods}

For the statistical analysis of the air temperature we have used 146-years long series of mean daily air temperature from the Hurbanovo observatory (Fig. 2) of the period 1872-2017. The meteorological station at Hurbanovo (with its former name Ó Gyalla - Stará Ďala) is a representative station for the relatively arid region of the Danubian lowland region (Petrovič, 1960; Konček, et al., 1974; Lapin, 2004; Faško et al., 2008; Halmová et al., 2015). The Hurbanovo station (latitude $47.9^{\circ} \mathrm{N}$; longitude $18.2^{\circ} \mathrm{E}$, $\mathrm{m}$ a.s.l.) ranks among the best meteorological stations in Central Europe providing sufficiently long, high quality, and homogenous observations. The meteorological observatory is situated in the large garden on the northern edge of the small city of Hurbanovo. Regular measurements of the air temperature $\left[{ }^{\circ} \mathrm{C}\right]$ and precipitation [mm] started in 1876 at this station. The period 1871-1875 was completed according to the Komarno station (distance of $20 \mathrm{~km}$ from Hurbanovo). The data are collected in the database of the Slovak hydrometeorological institute (SHMI). The climatic station Hurbanovo (115 $\mathrm{m}$ a.s.l.) is the representative station of the southwestern region of Slovakia. The air temperature observations were carried on climatic schedule on 7 a.m. $\left(T_{7}\right), 2$ p.m. $\left(T_{14}\right)$ and 9 p.m. $\left(T_{21}\right)$ of the middle local time in Slovakia. The daily mean of air temperature $\left(T_{d}\right)$ was recalculated according to formula: $T_{d}=\left(T_{7}+T_{14}+2 T_{21}\right) / 4$ in Hurbanovo after the year 1921. The series of mean daily air temperature was used to prepare three 146-years series of following air temperature indexes in ${ }^{\circ} \mathrm{C}$ :

$T_{d, \max }$ - series of maximum mean daily air temperature for each year (1 datum per year),

$T_{a}$ - series of mean annual air temperature (1 datum per year),

$T_{d, \min }$-series of minimum mean daily air temperature for each year ( 1 datum per year).

We can see the gradual increase of air temperature during the four periods at Hurbanovo in Table 1, where are the long-term characteristics of air temperature. The long-term mean air temperature increased by o $1.64^{\circ} \mathrm{C}$.

Table 1. Climatic station Hurbanovo, long-term mean daily air temperature $T_{d, \text { mean }}$, long-term minimum mean daily $T_{d m i n, a}$ and long-term maximum mean daily $\boldsymbol{T}_{\text {dmax }, a}$ air temperature during various periods in ${ }^{\circ} \mathrm{C}$

Tabul'ka 1. Klimatická stanica Hurbanovo, dlhodobá priemerná denná teplota vzduchu $T_{d, \text { mean }}$, dlhodobá minimálna priemerná denná $T_{d m i n, a}$ a dlhodobá maximálna priemerná denná $T_{d m a x, a}$ teplota vzduchu za rôzne obdobia $v^{\circ} \mathrm{C}$

\begin{tabular}{|l|c|l|l|}
\hline $\begin{array}{l}\text { Period } \\
\text { Obdobie }\end{array}$ & $\boldsymbol{T}_{\boldsymbol{d}, \text { mean }}$ & $\boldsymbol{T}_{\boldsymbol{d m i n}, \boldsymbol{a}}$ & $\boldsymbol{T}_{\boldsymbol{d m a x}, \boldsymbol{a}}$ \\
\hline $1872-1900$ & 9.11 & -24.2 & 28.7 \\
$1901-1930$ & 9.50 & -21.3 & 29.2 \\
$1931-1960$ & 9.77 & -21.4 & 30.2 \\
$1961-1990$ & 9.98 & -16.7 & 29.6 \\
$1991-2018$ & 10.75 & -14.8 & 32.0 \\
\hline
\end{tabular}

\section{Methods of T-year design values estimation}

The estimation of so called design values of air temperature occurrence or exceedance of certain probability is done by theoretical functions of probability density distribution (distribution functions) in meteorology and climatology. The 40-years series of observations can be applied for relatively credible estimation of extreme values with up to 100 years probability of exceedance/ non exceedance. These values become to be used in several branches, e.g. in health care (waves of heat or extreme cold), in engineering, or in hydrology (Kyselý, 
2002; 2004).

The selection of the theoretical distribution function is based on histograms. Histograms belong to basic statistical procedures of the graphical processing of the long time series. They allow showing of the frequency of values in individual classes during the selection of the theoretical frequency distribution function. If we want to assess the $T$-year design values of air temperature, we have to construct the distribution function for the given period. Histograms of the series of mean daily air temperature are bimodal in many cases (Fig. 3). The construction of the theoretical distribution function of mean daily air temperature with multimodal shape is a complicated problem. This problem can be avoided, e.g. by construction of the distribution curve for individual days of the year or individual months of the year. Such histograms are unimodal (single-peak), and in most of the cases the $T$-year design values can be estimated using the simple normal (Gaussian) distribution function. During the winter months of December to February the histograms are asymmetric, the temperatures near $0^{\circ} \mathrm{C}$ occur more frequently.

The other way how to solve this problem is to select each year single most extreme value of the selected characteristic, and to assess the $T$-year air temperature value using such processed time series. This approach was used in this study.

The results are presented for the station Hurbanovo, because this station offers the longest homogeneous series of observation since the year 1872 and it gives us the opportunity to analyze the changes of $T$-year design temperatures in different time periods.
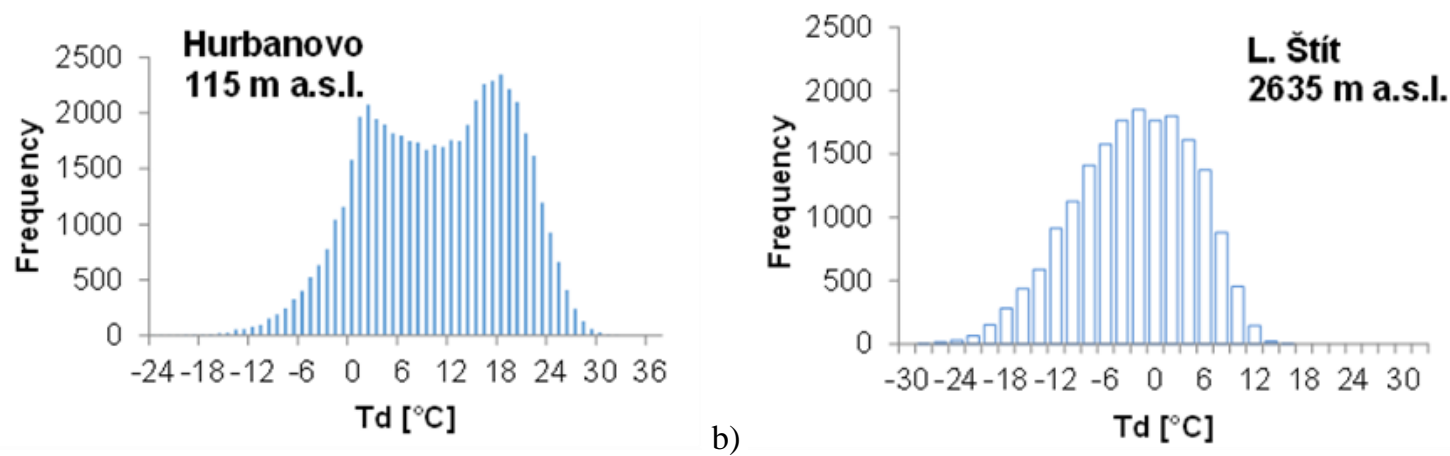

Fig. 1. Histogram of the mean daily air temperature $\left(T_{d}\right)$, a) in climatic station Hurbanovo, period 1872-2017, b) in climatic station Lomnický štit.

Obr. 1. Histogram súboru priemerných denných teplôt vzduchu $\left(T_{d}\right)$, a) v klimatickej stanici Hurbanovo, za obdobie 1872 - 2017, b) v klimatickej stanici Lomnický śtít.

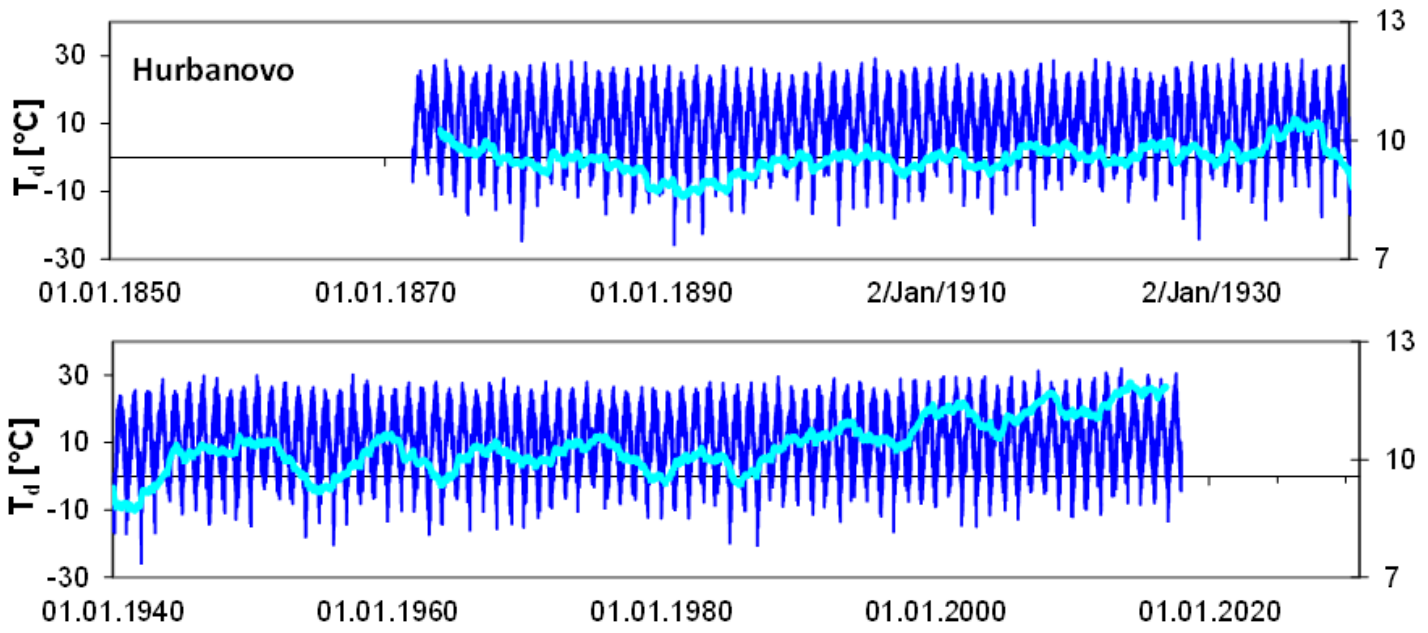

Fig. 2. Mean daily air temperature (dark blue line) in station Hurbanovo (1872-2017) and 4- year moving average of daily values (light green line, right axis).

Obr. 2. Priebeh priemerných denných teplôt vzduchu (tmavomodrá čiara) v stanici Hurbanovo (1872 - 2017) a priebeh 4-ročných klzavých priemerov denných hodnôt (svetlomodrá čiara, mierka je na osi vpravo). 


\section{Results}

\section{T-year design values of different air temperature indexes in Hurbanovo}

The basic assumption for the estimation of the distribution functions is the homogeneity and stationarity of the measured time series. It is generally valid that the air temperature series are not stationary, but they are influenced by multiannual variability and the long-term trend of increase (Brázdil et al., 1996; Hansen et al., 2010; Pekárová et al., 2011; Labudová et al., 2015, GISTEMP Team, 2019). The long-term development of the global air temperature over the world is plotted in Fig. 4 according to Hansen et al. (2010), the station Hurbanovo is not included in his set of stations. More information can be found at http://www.shmu.sk/sk/?page $=2049 \&$ id $=975$.

The development of time series of maximum, mean and minimum daily temperature at Hurbanovo is in Fig. 5. In Fig. $5 \mathrm{~b}$ we can see that the mean annual temperature series at Hurbanovo corresponds with the worldwide development of the global temperature during the period 1880-2017. During the period 1930-1985 the trend of mean daily temperature was negligible at Hurbanovo, but it has got significant increasing trend since the year 1985 . Therefore the air temperature series are not stationary at Hurbanovo. In order to partially eliminate this fact, we

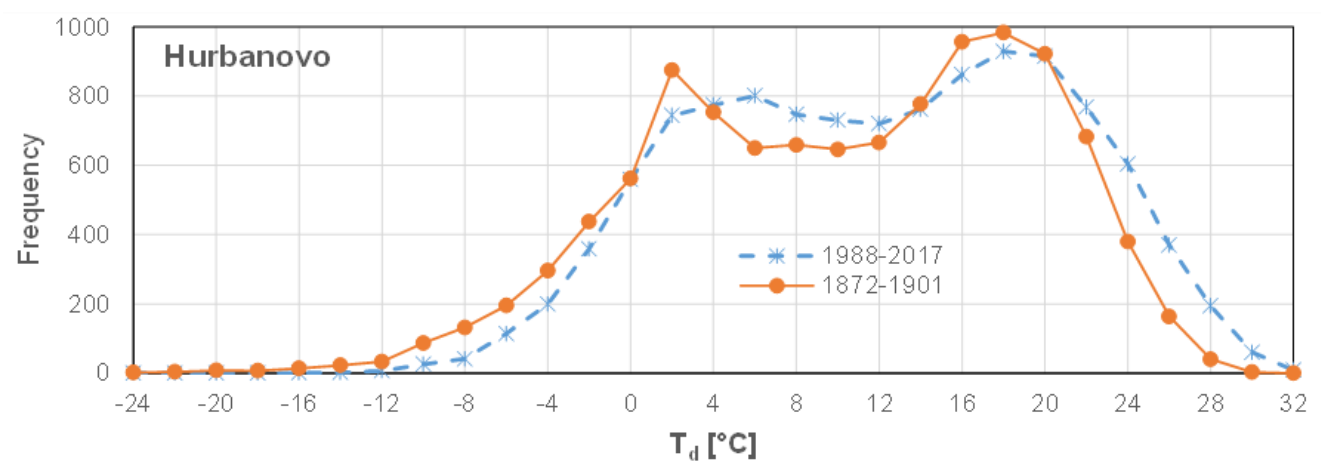

Fig. 3. Change of the distribution curve of the mean daily air temperature in station Hurbanovo. Full line with points - old 30-years period 1872-1901, dashed line-new 30-years period 1988-2017.

Obr. 3. Zmena distribučnej čiary priemerných denných teplôt vzduchu v stanici Hurbanovo. Plná čiara s bodmi - staré 30-ročné obdobie 1872 - 1901, prerušovaná čiara - nové 30-ročné obdobie $1988-2017$.

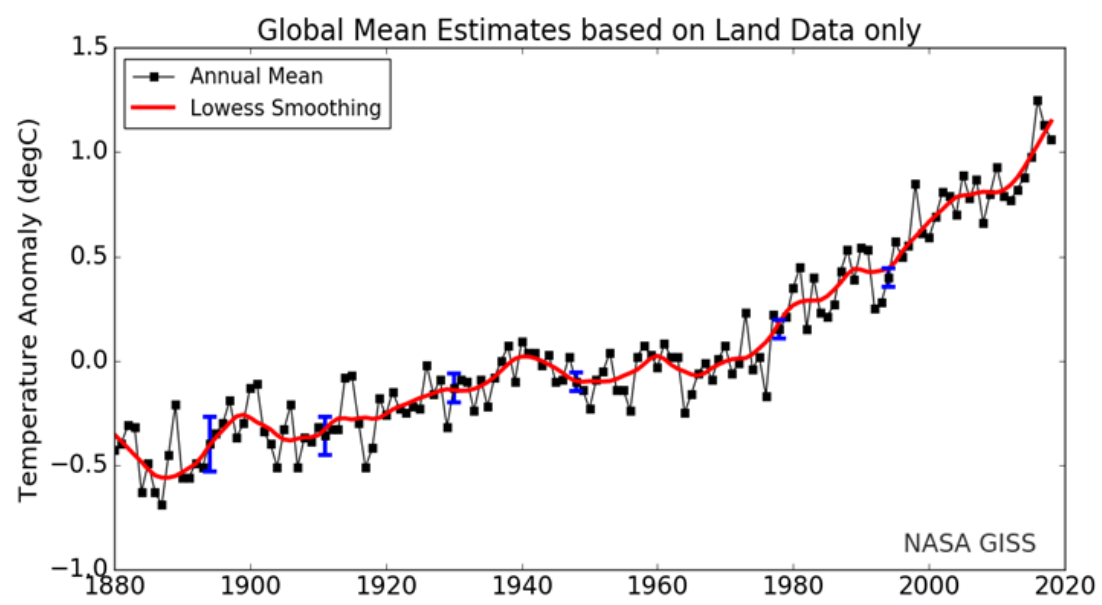

Fig. 4. Atmosphere temperature index, 1880 to present, differences to base period 19511980. The solid black line with dots is the global annual average and the solid red line is the five-year lowess smooth. [This is an update of Fig. 9a) in Hansen a kol. (2010) The black line with the points is the global annual average and the red line represents the five year filter].

Obr. 4. Index teploty atmosféry, odchýlky od obdobia 1951 - 1980. Čierna čiara s bodmi je globálny ročný priemer a červená čiara znázorňuje pät'ročný filter. [Aktualizácia obrázka 9a) v práci Hansen et al. (2010)]. 


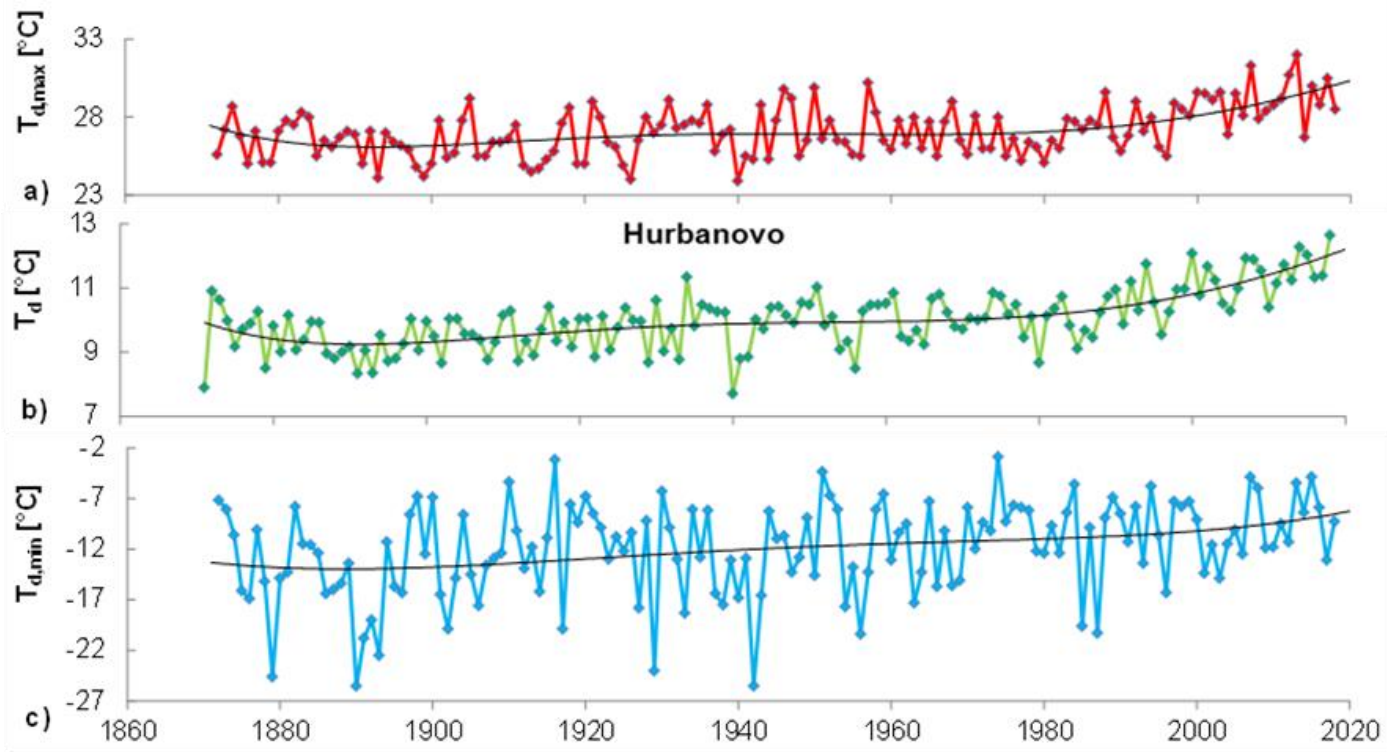

Fig. 5. Time series of annual air temperature indexes in station Hurbanovo (1872-2017), a) series of maximum mean daily air temperature of the year $T_{d, \max }, b$ ) series of mean annual air temperature of the year $\left.T_{d}, c\right)$ series of minimum mean daily air temperature of the year $T_{d . m i n}$. Obr. 5. Časový vývoj radov indexov ročných hodnôt teploty vzduchu v stanici Hurbanovo (1872 - 2017), a) rad maximálnych priemerných denných teplôt vzduchu za rok $T_{d, \max }$, b) rad priemernej ročnej teploty vzduchu v roku $\left.T_{d}, c\right)$ rad minimálnych priemerných denných teplôt vzduchu za rok $T_{\text {d.min. }}$

have subdivided the data series of the whole period 1872-2017 into four 60-years subperiods: 1. 1872-1931; 2. 1901-1960; 3. 1931-1990 and 4. 1958-2017 and we estimated the parameters of theoretical distribution functions for all subperiods. We are aware of the fact that even the 60-years periods do not fulfill the condition of stationarity, but if we want to estimate the 200 -year design values of air temperature, we need to apply the longer series.

We used software STATGRAPHICS PLUS for the statistical processing of the series. The graphical presentation of changes in statistical characteristics of three given series $\left(T_{d, \min }, T_{d}\right.$, and $\left.T_{d, \max }\right)$ is made using Boxand-Whisker plots (Fig. 6 left) for the whole period and for the four subperiods (subperiods are labeled as 1, 2, 3, 4). These plots demonstrate the significant statistical data of the time series. The plots divide data into 4 equal frequency regions. The rectangles include 50 percent of data; the mean value is plotted as vertical line inside the rectangle. The left horizontal line represents the first quartile, the right one the upper quartile. Individual points (small rectangles) show the temperatures exceeding certain limits (dubious extremes). The plots show the gradual shift to higher temperatures.

We have also calculated the basic statistical characterristics of the selected time series of Hurbanovo station for the whole period and four subperiods: 1. 1872-1931; 2. 1901-1960; 3. 1931-1990 and 4. 1958-2017. The results are summarized in Table 2 .
We have also tested the suitability of the Gaussian (normal) distribution for estimation of the probability distribution of the series. The statistical tests have shown, that for estimation of the $T$-year values of selected temperature indexes it is possible to apply the normal probability distribution. The right plots on Fig. 6 show the probability distribution of particular indexes, but only for three periods - the bold line for the whole period 1872-2017, the thin line for the oldest subperiod 1872-1931, and the middle line for the newest subperiod 1958-2017.

From the theoretical distribution functions we have estimated the $T$-year values of selected air temperature indexes for selected periods in station Hurbanovo. We have to notice that for the minimum temperatures we are interested in bottom/left end of the distribution curve probability of non exceedance $0,01 \%$, and for the maximum temperatures we are interested in upper/right end of the distribution curve - probability of exceedance $0,99 \%$ (in case of 100-year design values). Results of the basic statistical characteristics of studied three indexes and $T$ - year temperatures (50-, 100- and 200-year values) are in Table 2.

\section{Conclusions and discussion}

Variability of extreme air temperatures is in scope of interest of climatologists, hydrologists and the whole society in last decades, because it can impact the global 
hydrological cycle and energetic balance of the Earth. From the frequency analysis of the air temperature observations at Hurbanovo during last 146 years it follows that the statistically significant change has occurred of the distribution curve of the mean daily air temperature (Fig. 3).

Table 2. Basic statistical characteristics of the selected temperature series of the station Hurbanovo for the whole period and 4 subperiods: 1 . 18721931; 2. 1901-1960; 3. 1931-1990 and 4. 1958-2017

Tabul'ka 2. Základné štatistické charakteristiky vybraných teplotných radov zo stanice Hurbanovo za celá obdobie a v štyroch obdobiach: 1. 1872 1931; 2. 1901 - 1960; 3. $1931-1990$ a $4.1958-2017$

\begin{tabular}{|l|c|c|c|}
\hline & $\boldsymbol{T}_{\boldsymbol{d}, \boldsymbol{m i n}}$ & $\boldsymbol{T}_{\boldsymbol{d}}$ & $\boldsymbol{T}_{\boldsymbol{d}, \boldsymbol{m a x}}$ \\
\hline 1872-2017 & & & \\
Mean & -12.00 & 10.00 & 27.07 \\
Std. Dev. & 4.58 & 0.88 & 1.61 \\
50 & -21.41 & & 30.38 \\
100 & -22.65 & & 30.81 \\
200 & -23.80 & & 31.22 \\
\hline 1. 1872-1931 & & & \\
Mean & -13.11 & 9.52 & 26.43 \\
Std. Dev. & 4.92 & 0.64 & 1.35 \\
50 & -23.21 & & 29.20 \\
100 & -24.55 & & 29.56 \\
200 & -25.78 & & 29.90 \\
\hline 2. 1901-1960 & & & \\
Mean & -12.52 & 9.75 & 26.79 \\
Std. Dev. & 4.66 & 0.71 & 1.54 \\
50 & -22.09 & & 29.96 \\
100 & -23.36 & & 30.38 \\
200 & -24.52 & & 30.76 \\
\hline 3. 1931-1960 & & & \\
Mean & -11.81 & 9.97 & 27.01 \\
Std. Dev. & 4.43 & 0.71 & 1.39 \\
50 & -20.91 & & 29.86 \\
100 & -22.11 & & 30.24 \\
200 & -23.22 & & 30.58 \\
\hline $4.1958-2017$ & & & \\
Mean & -10.34 & 10.55 & 27.69 \\
Std. Dev. & 3.62 & 0.82 & 1.61 \\
50 & -17.78 & & 31.00 \\
100 & -18.76 & & 31.44 \\
200 & -19.67 & & 31.84 \\
\hline
\end{tabular}

In the present study the $T$-year values of air temperature were estimated for three temperature indexes in station Hurbanovo: 1. series of maximum mean daily air temperature of the year $T_{d, \max }, 2$. series of mean annual air temperature of the year $T_{d}$; and 3. series of minimum mean daily air temperature of the year $T_{d, m i n}$. Change in the theoretic distribution curve of the mean daily air temperature indexes were compared during two subperiods of the instrumental period 1872-2017. The 100-year minimum mean daily air temperature $T_{d, \min }$ was $-24.55^{\circ} \mathrm{C}$ in the span $1872-1931$, and $-18.76^{\circ} \mathrm{C}$ in the span 1958-2017, respectively. The 100-year maximum mean daily air temperature $T_{d, \max }$ was $30.81^{\circ} \mathrm{C}$ in the span $1872-1931$, and $31.44^{\circ} \mathrm{C}$ in the span $1958-2017$, respectively. Generally, the changes in temperature design values are more marked in case of minimum temperatures, e.g. the value of 100 -year minimum mean daily air temperature increased by more than $5^{\circ} \mathrm{C}$. The 100-year maximum mean daily air temperature increased by $1.88^{\circ} \mathrm{C}$ in Hurbanovo.

In two years' time the next 30 -years period of observations 1990-2020 will be available and we shall have a chance to update the analysis and to compare the development in different periods. Our results indicate that the temperature characteristics of the new period will differ significantly from the period 1961-1990, which was quite stable and calm in our region. The period 19311960 was more extreme. We suppose that even the 60- years period is not sufficient enough for estimation of $T$-year values. Therefore it is necessary to use the longest possible series for estimation of the $T$ - year values and not to settle with the assumption of the permanent temperature increase (Charvátová and Střeštík, 1995, 2004; Charvátová, 2008, Mörner, 2018). It is interesting that according to the study of Gasparrini et al. (2015) the low temperatures have more unfavorable impact on human mortality than high temperatures.

\section{Acknowledgement}

This report was supported by the project VEGA 2/0004/19 and project ITMS 26240120004 Center of Excellence of Integrated Flood Protection, supported by the Operational Program Research and Development financed by the European Regional Development Fund.

\section{References}

Brázdil, R., Budíkova, M., Auer, I., Bohm, R., Cegnar, T., Faško, P., Lapin, M., Gajič-Čapka, M., Zaninovič, K., Koleva, E., Niedzwiedz, T., Ustrnul, Z., Szalai, S., Weber, R., O. (1996): Trends of maximum and minimum daily temperatures in Central and Southeastern Europe. International Journal of Climatology, vol. 16, 765-782.

Faško, P., Lapin, M., Pecho, J. (2008): 20-year extraordinary climatic period in Slovakia. Meteorologický časopis, $11,99-105$.

Gasparrini, A., Guo, Y., Hashizume, M., Lavigne, E., Zanobetti, A., Schwartz, J., Tobias, A., Tong, S., Rocklöv, J., Forsberg, B., Leone, M., De Sario, M., Bell, M.L., Yue-Liang Leon Guo, Chang-fu Wu, Haidong Kan, Seung-Muk Yi, Micheline de Sousa Zanotti Stagliorio Coelho, Paulo Hilario Nascimento Saldiva, Yasushi Honda, Ho Kim, Armstrong, B. (2015): Mortality risk attributable to high and low ambient temperature: a multicountry observational study. Lancet 2015, vol. 
Box-and-Whisker Plot

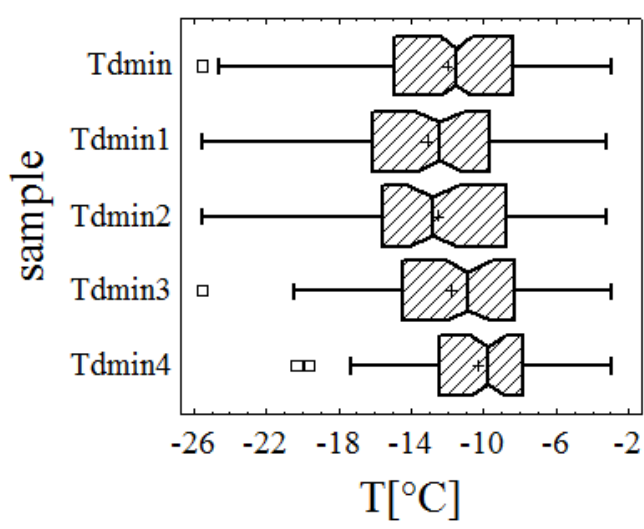

Box-and-Whisker Plot

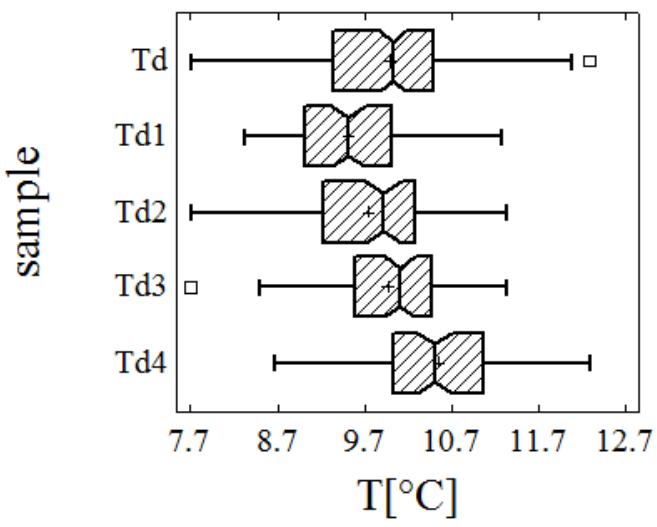

Box-and-Whisker Plot

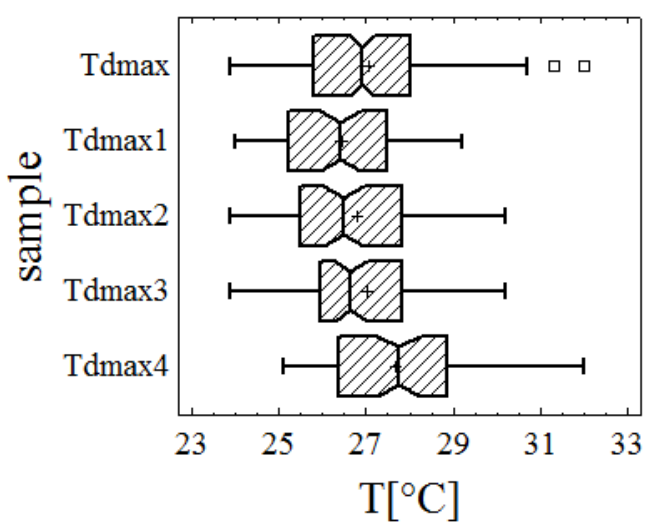

Normal Distribution

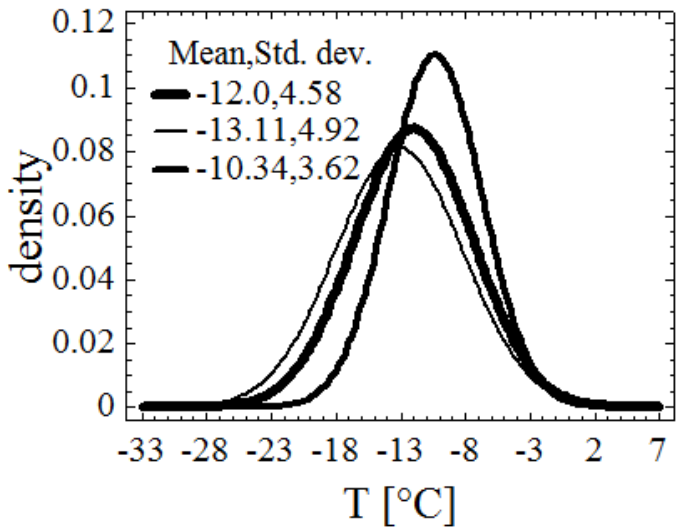

Normal Distribution

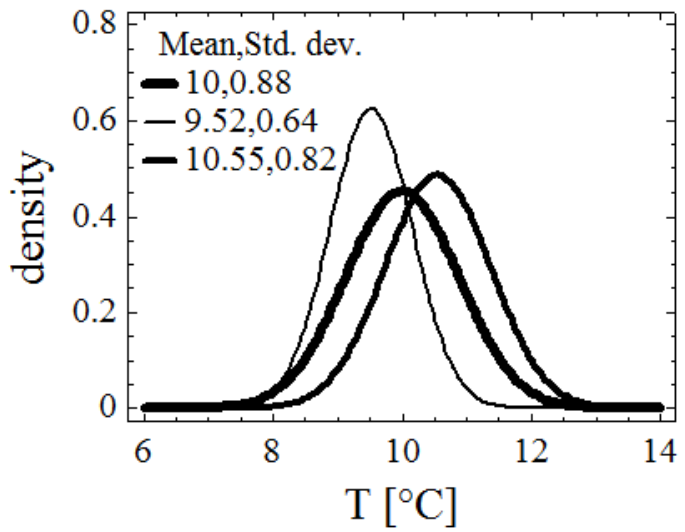

Normal Distribution

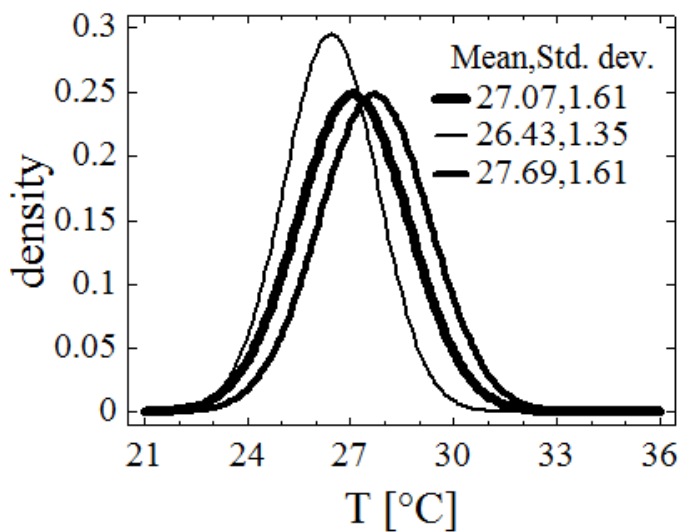

Fig. 6. Graphical presentation of differences between series: upper Td.min, center $T_{d}$; and below $T_{d, \max }$; left: Box and Whisker plot for the whole period and 4 subperiods; right: distribution densities for the whole period and two 60-years subperiods 1. 1901-1960 and 2. 1958-2017.

Obr. 6. Grafické znázornenie rozdielov radov: hore Td.min, $v$ strede $T_{d}$; a dole $T_{d, \max }$. vlavo: Box a Whisker obrázok za celé obdobie a 4 podobdobia; vpravo: hustoty rozdelenia za celé obdobie a dve 60-ročné obdobia 1. 1901 - 1960 a 2. 1958 - 2017. 
386, issue 9991, 369-375. DOI:https://doi.org/10. 1016/S0140-6736(14)62114-0.

GISTEMP Team, (2019): GISS Surface Temperature Analysis (GISTEMP). NASA Goddard Institute for Space Studies. Dataset accessed 2019-02-14 at https://data. giss.nasa.gov/gistemp/.

Halmová, D., Pekárová, P., Olbřímek, J., Miklánek, P., Pekár, J. (2015): Precipitation Regime and Temporal Changes Central Danubian Lowland Region. Advances in Meteorology, Vol 2015, Article ID 715830, 12.

Hansen, J., R. Ruedy, M. Sato, Lo, K. (2010): Global surface temperature change, Rev. Geophys., 48, RG4004, doi:10.1029/2010RG000345.

Charvátová, I., (2008): Long-term predictive assessments of solar and geomagnetic activities made on the basis of the close similarity between the solar inertial motions in the intervals 1840-1905 and 1980-2045. New astronomy, 14, 25-30.

Charvátová, I., Střeštík, J., (1995): Long-term changes of the surface air-temperature in relation to solar inertial motion. Climatic Change, 29, 3, 333-352.

Charvátová, I., Střeštík, J., (2004): Periodicities between 6 and 16 years in surface air temperature in possible relation to solar inertial motion. J. of Atmospheric and SolarTerrestrial Physic 66, 219-227.

Konček, M. (ed). (1974): Klíma Tatier. VEDA. Slovenská Akadémia Vied: Ústav Meteorlógie a Klimatol., 885.

Kyselý, J. (2002): Probability estimates of extreme temperature events: stochastic modelling approach versus extreme value distributions. Stud Geophys Geod 46: 93-112.

Kyselý, J. (2004): Mortality and displaced mortality during heat waves in the Czech Republic. Int. J Biometeorol. 91-97. DOI 10.1007/s00484-004-0218-2.

Labudová, L., Faško, P., Ivaňáková, G. (2015): Changes in climate and changing climate regions in Slovakia. Morav. Geogr. Rep., 23, 71-82.

Lapin, M., (2004): Detection of changes in the regime of selected climatological elements at Hurbanovo. Contr. to Geophysics and Geodesy. 34/2, 169-193.

Melo, M., Lapin, M. (2000): Teplotné scenáre pre Slovensko založené na výstupoch kanadských klimatických modelov. Geografický časopis, 52(2): 151-165.

Melo, M., Lapin, M., Damborská, I. (2007): Detection of climatic trends and variability at Hurbanovo. In: Střelcová, K., Škvarenina, J., Blaženec, M. [eds.]: "Bioclimatology and natural hazards". Presented at International Scientific Conference, Pol'ana nad Detvou, Slovakia, September 12.-20. 2007.

Mörner, N., A. (2018): Anthropogenic Global Warming (AGW) or Natural Global Warming (NGM). Voice of the Publisher. Vol.04 No.04, 51-59. https://www. scirp.org/journal/vp/.

Pekárová, P., Miklánek, P., Halmová, D., Onderka, M., Pekár, J., Kučárová, K, Liová, S., Škoda, P. (2011): Longterm trend and multi-annual variability of water temperature in the pristine Bela River basin (Slovakia). J. Hydrol., no. 400, 333-340.

Pekárová, P., Miklánek, P., Pekár, J. (2018): Why do some places show a bimodal distribution of daily air temperature?, manuscript of paper, 18.

Petrovič, Š. (ed), (1960): Klimatické pomery Hurbanova. HMÚ, Praha, 138 - 161. Petrovic, S. Ed., Climate Conditions of Hurbanovo (Slovakia), Hydrometeorological Institute, Prague, Czech Republic, 1960.

SHMÚ http://www.shmu.sk/sk/?page=2049\&id=975.

Szolgay, J. Hlavčová, K. Kalaš, M. (2002): Určovanie vplyvu klimatickej zmeny na odtokový proces. J. of Hydrol. Hydromech., 50, 4., 341-371.

Szolgay, J., Hlavčová, K., Lapin, M., Parajka, J., Kohnová, S. (2007): Vplyv zmeny klímy na odtokový režim na Slovensku. Key Publishing, Ostrava, 152.

Výberči, D., Pecho, J., Faško, P., Bochníček, O. (2018): Teplé a chladné obdobia na Slovensku (1951-2017) v kontexte klimatickej zmeny. Meteorol. J., 21, č. 2, 101 108. ISSN 1335-339X.

\section{VPLYV VODY NA BIMODALITU DISTRIBUČNÝCH FUNKCIÍ TEPLOTY VZDUCHU A ZMENY $N$ - ROČNÝCH HODNÔT TEPLOTY VZDUCHU V HURBANOVE}

Prírodné procesy majú zvyčajne jednovrcholový symetrický tvar histogramu (distribučnej funkcie). $\mathrm{V}$ prípade teploty vzduchu to platí napr. pre rady priemerných ročných teplôt vzduchu, alebo rady sezónnych teplôt. Vo väčšine staníc na svete však nadobúda rozdelenie denných hodnôt teploty vzduchu bimodálny tvar. K týmto staniciam patrí i väššina staníc na Slovensku. Napr. v stanici Hurbanovo (obr. 1a), histogram priemerných denných teplôt vzduchu, ale aj histogramy minimálnych/maximálnych denných teplôt majú dvojvrcholový/bimodálny tvar.

Z obrázku 1a) je zretel'ne vidiet', že jeden vrchol sa vyskytuje v triede okolo $2{ }^{\circ} \mathrm{C}$. Bimodalita histogramu radu priemerných denných teplôt vzduchu sa zvyčajne vysvetl'uje rôznymi podmienkami za letné a zimné obdobie. My sa domnievame, že príčinou zvýšeného výskytu denných teplôt okolo 0 až $2{ }^{\circ} \mathrm{C}$ je množstvo tepla, ktoré je potrebné na zmenu skupenstva vody v širokom okolí klimatickej stanice (v atmosfére, v pôde, $\mathrm{v}$ riekach a jazerách) na l'ad a naopak (Pekárová a kol., rukopis). Teplota okolo $0{ }^{\circ} \mathrm{C}-2{ }^{\circ} \mathrm{C}$ sa tým pádom vyskytuje častejšie, má väššiu početnost'. Vo vysokohorských staniciach (Lomnický štít), kde je priemerná ročná teplota vzduchu okolo $0{ }^{\circ} \mathrm{C}$ tieto dva vrcholy splývajú do jedného vrcholu a histogram nadobúda jednovrcholový/ unimodálny tvar (obr. 1b).

Bimodalita distribučných funkcií radov teplôt komplikuje možnosti odvodenia teoretickej distribučnej funkcie uvedených denných radov údajov a tým aj odhad rozdelenia denných (minimálnych, priemerných, maximál- 
nych) teplôt vzduchu v budúcnosti pri očakávanom oteplení atmosféry na základe historických pozorovaní. Pritom poznanie budúceho vývoja týchto hodnôt stojí v centre záujmu každej krajiny. V tomto článku sme sa zamerali na zhodnotenie zmien teoretických distribučných čiar pre rady vybraných indexov minimálnych a maximálnych (priemerných denných) teplôt vzduchu v stanici Hurbanovo za štyri 60-ročné časové obdobia: 1872 1931, 1901 - 1960, 1931 - 1990, 1958 - 2017. Pri štatistickej analýze teploty vzduchu sme použili 146-ročný rad priemerných denných teplôt vzduchu z observatória v Hurbanove (obr. 2) za obdobie 1872 - 2017. Z radu priemerných denných teplôt vzduchu sme zostavili tri 146-ročné rady teplotných indexov $\mathrm{v}{ }^{\circ} \mathrm{C}$ :

$T_{d, \max }-$ rad maximálnych priemerných denných teplôt vzduchu v roku (1 údaj za rok),

$T_{a} \quad-$ rad priemerných ročných teplôt vzduchu (1 údaj za rok),

$T_{d, \text { min }}$ - rad minimálnych priemerných denných teplôt vzduchu v roku (1 údaj za rok).

Základným predpokladom odhadu distribučných funkcií je homogénnost' a stacionárnost' nameraných časových radov. Vo všeobecnosti platí, že rady teplôt vzduchu nie sú stacionárne, ale sú ovplyvnené viacročnou variabilitou a dlhodobým rastúcim trendom. Dlhodobý vývoj globálnej teploty vzduchu podl'a Hansena a kol. (2010) na svete je znázornený na obr. 4 (v súbore staníc podla Hansena nie je zahrnutá stanica Hurbanovo).

Časový priebeh radu maximálnej dennej, priemernej a minimálnej dennej teploty v Hurbanove je znázornený na obr. 5 . Z obrázku 5b vidiet', že priebeh ročnej teploty v Hurbanove za obdobie 1880 - 2017 korešponduje s dlhodobým vývojom globálnej teploty vo svete. Napr. zatial' čo v období 1930 - 1985 bol trend radu priemernej dennej teploty v Hurbanove zanedbatel'ný, po roku 1985 má výrazný rastúci trend. Rady teploty vzduchu v Hurbanove teda nie sú stacionárne. Aby sme aspoň sčasti eliminovali tento fakt, rozdelili sme súbor údajov za celé obdobie 1872 - 2017 na štyri 60-ročné podobdobia: 1. 1872 - 1931; 2. 1901 - 1960; 3. 1931 - 1990 a 4. $1958-2017$ a aj pre ne sme odhadli parametre teoretických distribučných funkcií. Uvedomujeme si, že ani 60-ročné obdobie nesplńa podmienku stacionárnosti, ale ked'že chceme odvodit' 200-ročné návrhové hodnoty teploty vzduchu, je potrebné použit' dlhší rad.

Pri štatistickom spracovaní sme použili softvér STATGRAPHICS PLUS. Na grafické znázornenie zmien štatistických charakteristík daných troch radov $\left(T_{d, \min }, T_{d} a T_{d, \max }\right)$ pre celé obdobie a $\mathrm{v}$ štyroch podobdobiach (podobdobia sú značené $1,2,3,4)$ sme použili grafy Box-and-Whisker (obr. 6 vl'avo). Tento graf zobrazuje dôležité štatistické údaje o rade hodnôt. Graf rozdel'uje údaje na štyri rovnaké oblasti frekvencie. Obdížniky obklopujú 50 percent údajov; stredná hodnota je vykreslená ako vertikálna čiara vo vnútri obdížnika. Lavá (dolná) horizontálna čiara znázorňuje prvý kvartil, pravá čiara znázorňuje horný kvartil. Jednotlivé body na grafe znázornené malými štvorčekmi, znázorňujú teploty, kto- ré prekračujú isté hranice (podozrivé extrémy). $Z$ grafov vidiet' postupný prechod $\mathrm{k}$ vyšším hodnotám teplôt.

Ďalej sme vypočítali základné štatistické charakteristiky vybraných teplotných radov zo stanice Hurbanovo pre celé obdobie a v štyroch podobdobiach: $1.1872-1931$; 2. $1901-1960 ; 3.1931-1990$ a 4. 1958 - 2017. Výsledky sú zhrnuté v tabul'ke 2.

Následne sme testovali vhodnost' použitia Gaussovho (normálneho) rozdelenia na odhad rozdelenia pravdepodobnosti výskytu daných radov. Zo štatistických testov vyplynulo, že na odhad $N$-ročných hodnôt radov vybraných teplotných indexov je možné použit' normálne rozdelenie pravdepodobnosti. Na pravých grafoch obrázku 6 sú vykreslené rozdelenia pravdepodobnosti pre jednotlivé indexy, ale len pre tri časové obdobia - najhrubšou čiarou pre celé obdobie 1872 - 2017, pre najstarší rad 1. obdobie 1872 - 1931, a pre najnovší rad - 4. obdobie 1958 - 2017.

$\mathrm{Z}$ teoretických distribučných funkcií sme odhadli $N$-ročné hodnoty vybraných indexov teploty vzduchu $\mathrm{v}$ stanici Hurbanovo pre dané obdobia. Treba upozornit', že pre minimálne teploty nás zaujíma dolný/l’avý koniec distribučnej čiary - pravdepodobnost' podkročenia $0,01 \%$, a pre maximálne teploty horný/pravý koniec distribučnej čiary - pravdepodobnost' prekročenia $0,99 \%$ (pre 100-ročné návrhové hodnoty). Výsledky základných štatistických charakteristík daných troch indexov a $N$-ročné teploty (50-, 100- a 200-ročné hodnoty) sú uvedené $\mathrm{v}$ tabul'ke 2.

Variabilita extrémnych teplôt vzduchu je v posledných desatročiach $\mathrm{v}$ centre záujmu klimatológov, hydrológov, i celej spoločnosti, nakol'ko môže mat' vplyv na celosvetový hydrologický cyklus a energetickú rovnováhu na Zemi. Z frekvenčnej analýzy meraní teploty vzduchu v klimatickej stanici Hurbanovo za plynulých 146 rokov vyplýva, že došlo k štatisticky významnej zmene distribučnej čiary radu priemerných denných teplôt vzduchu (obr. 3).

V príspevku sme sa sústredili na zostrojenie teoretických distribučných čiar radov minimálnych a maximálnych priemerných denných teplôt vzduchu (jedna hodnota za rok) za účelom odhadu ich $N$-ročných návrhových hodnôt. V tejto práci prezentujeme výsledky z klimatickej stanice Hurbanovo. Napr. 100-ročná minimálna priemerná denná teplota radu $T_{d, \min } \mathrm{v}$ období $1872-1931$ bola $-24,55{ }^{\circ} \mathrm{C}$ a v období $1958-2017-18,76{ }^{\circ} \mathrm{C}$. Storoč-ná maximálna priemerná denná teplota radu $T_{d, \max }$ v období $1872-1931$ bola $30,81{ }^{\circ} \mathrm{C}$ a v období 1958 $201731,44^{\circ} \mathrm{C}$. Vo všeobecnosti výraznejšie zmeny návrhových hodnôt teplôt nastali v prípade minimálnych teplôt, hodnoty 100 -ročnej teploty sa zvýšili o viac ako $5^{\circ} \mathrm{C}$. Sto ročná maximálna teplota sa zvýšila „len“ o $1,88^{\circ} \mathrm{C}$. Za dva roky bude dokončené d'alšie 30-ročné obdobie pozorovaní 1990 - 2020 v meteorológii využívané na výpočty charakteristík meteorologických údajov. Naše výsledky naznačujú, že v porovnaní s obdobím 1961 1990 sa výrazne zmenia teplotné charakteristiky a to nielen v stanici Hurbanovo. Obdobie 1961 - 1990 bolo z dlhodobého hl'adiska rozptylu teplôt vzduchu v našom 
regióne obdobie netypicky pokojné. Obdobie 1931 1960 bolo extrémnejšie. Domnievame sa, že aj 60-ročné obdobie je nepostačujúce na $N$-ročných hodnôt. Preto na určenie $N$-ročných teplôt je potrebné použit čo najdlhšie rady pozorovaní a neuspokojit' sa s predpokladom trva- lých rastov teploty vzduchu (Charvátová a Střeštík, 1995; 2004; Charvátová, 2008; Mörner, 2018). Zo štúdie Gasparrini a kol. (2015) vyplýva, že nízke teploty majú nepriaznivejší vplyv mortalitu človeka, než vysoké teploty.

RNDr. Pavla Pekárová, DrSc.

RNDr. Pavol Miklánek, PhD.

Ústav hydrológie SAV

Dúbravská cesta č. 9

84104 Bratislava

E-mail: pekarova@uh.savba.sk

Doc. RNDr. Ján Pekár, CSc.

Katedra aplikovanej matematiky a štatistiky

Fakulta matematiky, fyziky a informatiky UK

Mlynská dolina

84248 Bratislava 